\title{
Comparison between aerated static piles and vermicomposting in producing co-compost from rural organic wastes and cow manure
}

\author{
M. A. Abdoli ${ }^{1}$ - G. Omrani ${ }^{2}$ - M. Safa ${ }^{3}$ S. Samavat ${ }^{4}$
}

Received: 4 April 2017/Revised: 2 July 2017/Accepted: 11 October 2017 /Published online: 25 October 2017

(C) The Author(s) 2017. This article is an open access publication

\begin{abstract}
In this study, the process of producing compost from rural separated solid wastes using aerated static piles (ASP) and vermicomposting was investigated which was carried out from September 2015 to January 2016. A combination of waste ingredients, conditions, processing duration, analysis of key parameters (moisture, $\mathrm{pH}$, temperature and $\mathrm{C} / \mathrm{N}$ ratio) governing the process, the quality of the final product and economic assessment was considered. Six piles were created in the ASP method, and six piles were loaded in vermicomposting pits in which the Eisenia foetida species was used. Three piles in each method (odd piles) contained 100\% putrescible wastes, while the rest of three piles (even piles) contained $75 \%$ putrescible wastes and $25 \%$ cow dung. The total coliform reductions in both kinds of waste compositions were observed. Heavy metals such as lead, cadmium and nickel were not found in any of the piles. Comprehensive statistical analysis, including the comparison of the variables, correlation among variables and analysis of variance, was performed for the measured parameters. Comparing the final product with standards showed that composting
\end{abstract}

Editorial responsibility: M. Borghei.

M. Safa

mahyarsafa77@yahoo.com

1 Department of Environmental Engineering, Faculty of Environment, University of Tehran, Tehran, Iran

2 Department of Environmental Engineering, School of Public Health, Tehran University of Medical Sciences, Tehran, Iran

3 Department of Environmental Engineering (Solid Waste Branch), Faculty of Environment, University of Tehran, Tehran, Iran

4 Department of Soil Fertility and Plant Nutrition Studies, Soil \& Water Research Institute, Karaj, Iran proceeded satisfactorily in both methods. There were no issues such as bad smells or rodents during the study. An approximate chemical empirical formula calculated for the organic fraction of the composts generated in vermicompost pits and ASP was $\mathrm{C}_{15.1} \mathrm{H}_{22.4} \mathrm{O}_{7.7} \mathrm{~N}$ and $\mathrm{C}_{15.2} \mathrm{H}_{21.5} \mathrm{O}_{14.3} \mathrm{~N}$, respectively. Economic assessment showed that net present value in the internal rate of return for producing compost using aerated static piles was equal to $12.4 \%$; for vermicomposting, it was $5.4 \%$.

Keywords Aerated static piles - Vermicompost $\cdot \mathrm{C} / \mathrm{N}$ ratio . Economic assessment

\section{Introduction}

Studies conducted in rural areas and small communities in Iran show the necessity of proper management of organic wastes to meet the current challenges and future needs of local residents. About $30 \%$ of Iran's population is concentrated in rural areas and so more attention to the rural environment is necessary. Currently, more than 10,000 tons of waste is produced daily in rural areas, which about $52.4 \%$ of its components are putrescible and have good potential to be converted into compost. Using this potential for the recovery of putrescible materials (more than 5000 tonnes per day) to organize the rural waste management system by rural municipalities is one of the important issues in rural solid waste management in the country, especially in recent years (IMRMO 2010). A report prepared by Iranian Municipalities and Rural Municipalities Organization (IMRMO) in 2016 indicates that household waste production is about 10,500 tons per day, and its putrescible component is about $54-55 \%$. Stability is one of the most important properties of compost obtained from the 
organic fraction of municipal solid wastes. This property is essential for the application of compost to land to avoid further field degradation and emissions of odours, among others (Barrena et al. 2014). Transporting organic wastes into inappropriate landfill sites has increased environmental pollution in most rural areas. Converting organic wastes into compost and reducing the volume of wastes transported to landfills play a significant role in reducing environmental pollution in rural areas, especially in villages located in coastal areas. ASP composting eliminates the need to turn the compost pile by inducing airflow into the piles. Furthermore, ASP composting dramatically reduces the cost of composting operations (fuel, labour and equipment maintenance) (Tchobanoglous and Kreith 2002). In this study, the ASP method was used to recover the rural waste. ASP composting is well suited to most types of feedstock including green wastes, kitchen wastes, bio-solids and all varieties of animal manure. Aerobic conditions will be maintained throughout the compost pile, and temperature will be controlled in ASP by adjusting the amount of airflow. This will accelerate the composting process and help to produce high-quality compost that is free of pathogens, parasites and weed seeds. There is the possibility to control unpleasant odours and insects in this technology (Bertoldi et al. 1996; Brown and Gage 2015). On the other hand, vermicomposting has a lot of properties because if properly treated, it will have good benefits to use in rural agricultural lands and will be a perfect solution for keeping the soil system alive and active (Abdoli and Roshani 2007). The large quantity of animal manure is difficult to be completely utilized in a limited nearby arable land, and fresh animal manure is also not suitable for land application because of its containing pathogens, unstable nutrients and transportation cost issues (Qian et al., 2014). Choosing the appropriate technology (ASP, vermicomposting) is very important for rural municipalities in terms of the quality of the finished compost, time required for producing compost, ease of preparation and lower costs. Composting technologies and control systems have reached an advanced stage of development, but these are too complex and expensive for most agricultural practitioners for treating livestock slurries. The development of simple but robust and cost-effective techniques for composting animal manures and solid wastes is therefore required to realize the potential benefits of waste sanitation and soil improvement associated with composted livestock manures (Brito et al. 2012). Temperature, aeration and types of the input materials regulate the process of co-composting. Most widely used co-composted materials are animal manures with agro-wastes or solid waste. Co-composting produces a valuable compost material that can be used as valuable soil amendment. The process of the co-composting and control of the composting factors are the current challenges for the researchers. There are different factors that govern the quality, stability and the maturity of the cocompost in terms of amount of plant nutrients and reduction in heavy metals. Among these, $\mathrm{C} / \mathrm{N}$ ratio is a parameter that can affect the loss of plant nutrients (Anwar et al. 2015). Therefore, in this study, the performance of the ASP method to produce compost in rural areas is evaluated and then compared with the performance of vermicompost in terms of different compositions of input materials, compost maturation, physical, chemical and biological properties of the final products as well as the economic assessment of these methods. The research was conducted in the village of Sooleghan, located in Tehran County.

\section{Materials and methods}

The pilot used in this study consists of 12 piles, six piles used in ASP resembles triangular shapes and six piles in vermicomposting pits. The odd piles (Numbers 1, 3 and 5) contained $100 \%$ putrescible wastes, and even piles (Numbers 2, 4 and 6) contained $75 \%$ putrescible wastes and $25 \%$ cow dung in each method. To estimate the variables related to process maturity and identify reading errors in a better manner, three replications in each method were used. In the static method, to create piles, a compost pad with a length of $10 \mathrm{~m}$, a width of $2 \mathrm{~m}$ and a proper slope to drain the possible leachate was established. In this method, the size of piles was equal to $1.5 \times 1 \times 0.9 \mathrm{~m}$ (Fig. 1a). An appropriate roof was established to prevent excess moisture from rainfall or loss due to evaporation by the sun.

It is to be noted the volume of material loaded in both methods is the same and equal to 0.675 cubic metres for each pile. Aeration pipes' diameter, the holes' diameter and their spacing (the distance between holes in the same row) were calculated to be $3.3,1$ and $10 \mathrm{~cm}$, respectively. The perforated section of the aeration pipe was considered about $1.1 \mathrm{~m}$ and was embedded in a porous base of gravel and wood chips, $1 / 4$ the width of the pile $(25 \mathrm{~cm})$, to avoid clogging the holes. For proper distribution of air in the aeration pipes, 24 holes in two rows at 5 and 7 o'clock, facing downward (at an angle of $60^{\circ}$ between the rows), have been considered in each pipe. The number and size of the holes should provide a total area equal to two times the cross-sectional area of the pipe (Alberta Environment \& Olds College 1999). Based on the elemental analysis of three samples of the input waste and using the obtained analytical data, the approximate chemical empirical formula calculated for rural organic wastes was $\mathrm{C}_{24.5} \mathrm{H}_{36.8}$ $\mathrm{O}_{28.8} \mathrm{~N}$. Next, using the formula of aerobic stabilization of organic wastes (Tchobanoglous and Kreith 2002), aerator pump capacity was calculated to be $2.1 \mathrm{~m}^{3} / \mathrm{min}$. For elemental analysis of the samples, an automated thermal 
Fig. 1 a ASP and

b vermicomposting site plan

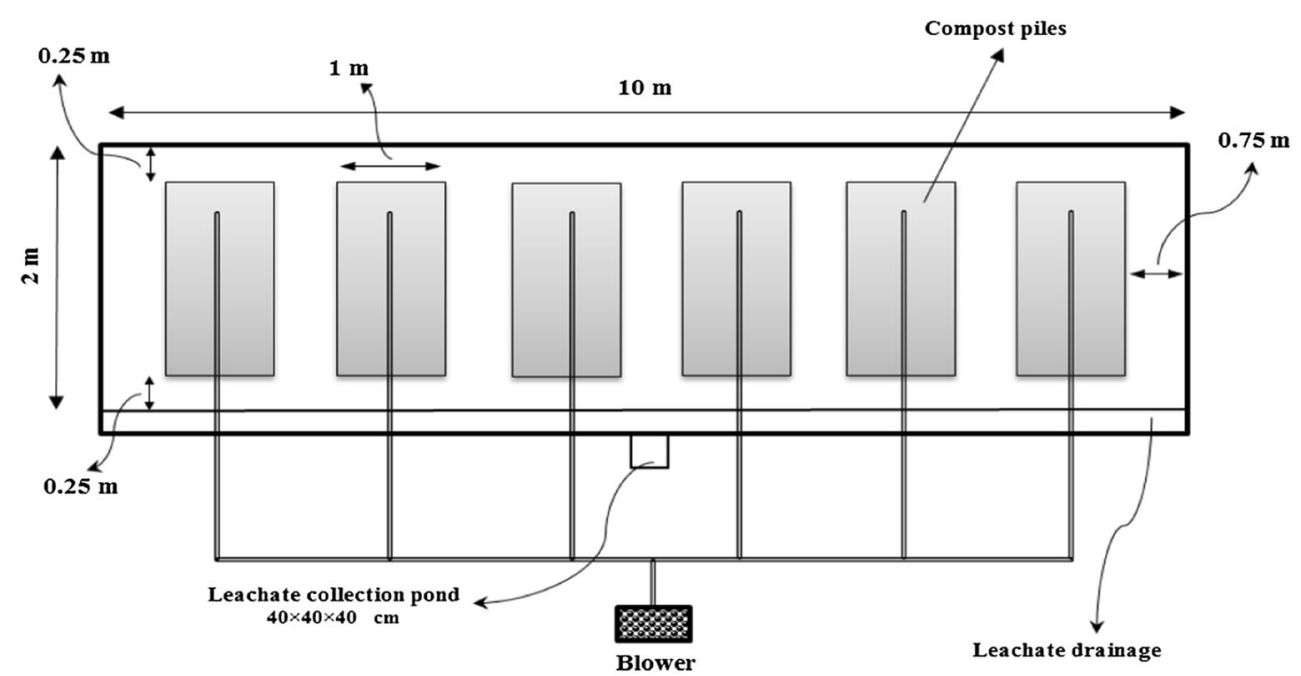

(a)

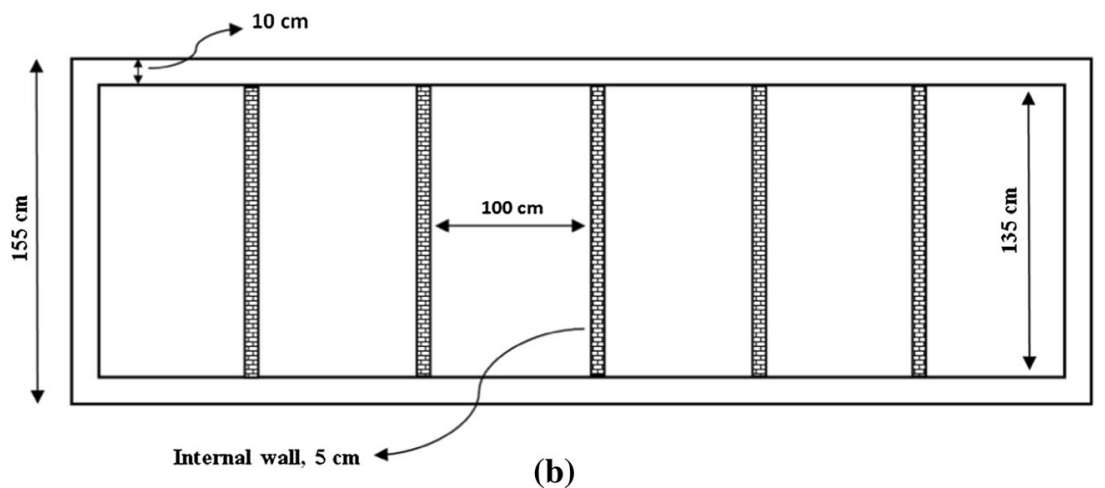

elemental analyser (Costech Analytical TechnologiesModel: Eager300-EA1112) was used. This high-temperature combustion system provides immediate results in the conversion of substances into gases. A small amount of sample in a capsule drops inside an oxidation/reduction reactor kept at a temperature of $1000{ }^{\circ} \mathrm{C}$ (Razmjoo et al. 2015). To prepare the samples, $10 \mathrm{mg}$ of dried and milled samples was encapsulated by aluminium foil and placed into the auto-sampler stages of the elemental analyser. The instrument was calibrated before introducing the samples.

In this study, to produce vermicompost, six rectangular pits with internal dimensions of $1.35 \times 1 \times 0.5 \mathrm{~m}$ were constructed using Eisenia foetida species as composting worms. The vermicomposting site plan is shown in Fig. 1b. For circulating the air into the vermicomposting piles, some holes were made in the walls between pits, and also, the pits bed was prepared for the activity of the composting worms by putting cartons and cardboards. Pre-compost is necessary to avoid earthworm mortality (Mupondi et al. 2011).

Finally, after loading the 12 piles in both systems, the process of composting within 112 days was monitored. For 25 non-consecutive days, four variables-moisture, $\mathrm{pH}$, ambient temperature and temperatures of the piles-were measured in situ by laboratory equipment (Lutron moisture meter, Model MS-7011, pen type AZ pH meter, Model 8685 and Lutron thermometer, Model TM-914C). To measure these variables, the protocol of testing methods provided by TMECC (2002) was used. To determine the $\mathrm{C} / \mathrm{N}$ ratio, 25 samples were taken at the desired dates and sent to the laboratory for measurement.

The necessary tests to determine the physical/chemical and microbial characteristics of the input wastes and finished compost have been conducted on the samples. The emitted ammonia was measured by the ammonia gas detector tube and GASTEC pump model 801. Based on the designed amount of air required for aeration, a regular schedule for aeration control (blower working in the morning and afternoon) has been performed by a 24-h analogue timer device (theben). Compost sampling was performed under the terms and the protocol provided by 'TMECC-02.01' instructions, entitled 'Field sampling of compost materials', subsection (02.01-A), version 2002 (Brinton et al. 2012; WEL 2016; TMECC 2002). To evaluate data descriptive statistics (mean and standard deviation) and the correlation of measured parameters in 
the composting process (through the parametric Pearson test and the nonparametric Spearman test), SPSS software version 23 was used. To compare the relationship between parameters at different stages of composting, ANOVA was used.

\section{Results and discussion}

The average density for input organic wastes was measured equal to $383 \mathrm{~kg} / \mathrm{m}^{3}$. For samples with a mixture of $75 \%$ organic wastes and $25 \%$ cow dung (decomposed for 5 days), the amount of density was measured about $422 \mathrm{~kg} /$ $\mathrm{m}^{3}$. To determine the characteristics of the input material, four samples including two samples of $100 \%$ putrescible wastes and two samples of the mixture of $75 \%$ organic waste and $25 \%$ cow dung, as well as a sample of only cow dung, were taken and sent to the laboratory. The results are shown in Table 1.

Physical analysis of wastes produced in the village due to the sampling conducted in the summer, indicates that about 58\% of input wastes used in composting site are putrescible and have a density of $383 \mathrm{~kg} / \mathrm{m}^{3}$. As it is shown in Table 1, the amount of $\mathrm{pH}$, total coliforms, faecal coliforms and parasite eggs in samples included 25\% cow dung is more than other samples. In contrast, carbon-tonitrogen ratio in samples included $25 \%$ cow dung is less than the other two samples because of more nitrogen content in cow dung.

Cow manure (with initial moisture content $45 \%$ ) used in this study had a pH of 7.8 and total nitrogen equal to 1.81 . $\mathrm{K}_{2} \mathrm{O}, \mathrm{P}_{2} \mathrm{O}_{5}$ and $\mathrm{EC}$ were about $1.42,0.54 \%$ and $18.9 \mathrm{Ds} / \mathrm{m}$, respectively. These outputs are in agreement with the results presented by Huang et al. (2017). The $\mathrm{C} / \mathrm{N}$ ratio of the cow dung itself is in low ratio which is good to help the compost in the maturity process (Kadir et al. 2016).
Table 2 indicates the results of the ultimate analysis (CHNS-O) of three input wastes and also of three final compost samples, as well as the $\mathrm{C} / \mathrm{N}$ ratio of the samples and the calculated empirical formula.

The results of the thermal elemental analysis of the samples presented in Table 2 show that the average elemental carbon content in matured vermicompost is about $21.60 \%$ and in ASP final product is $21.49 \%$ (a decrease of $36 \%$ compared to the raw materials in both products). In the case of hydrogen and oxygen, reduction in the final products is about 37 and $72 \%$ for vermicompost and 40 and $49 \%$ for ASP. Elemental sulphur content in both input wastes and mature compost samples was less than $0.5 \%$; however, in some samples, the analyser did not allow an accurate estimate of the sulphur content due to lack of precision. These results are in agreement with the results of a similar research conducted by Komilis et al. (2012). The formula of the final organic product obtained was $\mathrm{C}_{15.1} \mathrm{H}_{22.4} \mathrm{O}_{7.7} \mathrm{~N}$ for vermicompost and $\mathrm{C}_{15.2} \mathrm{H}_{21.5} \mathrm{O}_{14.3} \mathrm{~N}$ for ASP that, in comparison with the chemical formula of the input waste, have lighter molecular structure. The changes in the composition during the biodegradation process and the final waste composition are strictly dependent on the process conditions (Liwarska-Bizukojc and Ledakowicz 2003).

\section{Statistical analysis of the measured data}

Descriptive statistics of the measured data-moisture, $\mathrm{pH}$, temperatures of the piles and the $\mathrm{C} / \mathrm{N}$ ratio-based on the waste components $(100 \%$ waste $/ 75 \%$ waste and $25 \%$ cow dung) are provided in Table 3. As can be seen in this table, the average temperature of the masses loaded in the ASP method is about $3.94{ }^{\circ} \mathrm{C}$ higher than the average temperature of the vermicompost masses. This can be due to the aeration of the masses in the ASP method. The average

Table 1 Specifications of input organic wastes after separation

\begin{tabular}{lllllllll}
\hline $\begin{array}{l}\text { Sample } \\
\text { number }\end{array}$ & $\begin{array}{l}\text { Sample } \\
\text { weight } \\
(\mathrm{Kg})\end{array}$ & Sample specifications & $\begin{array}{l}\text { Moisture } \\
(\%)\end{array}$ & $\mathrm{pH}$ & $\begin{array}{l}\mathrm{C} / \mathrm{N} \\
\text { ratio }\end{array}$ & $\begin{array}{l}\text { Total coliform } \\
(\mathrm{MPN} / \mathrm{gww})\end{array}$ & $\begin{array}{l}\text { Faecal coliforms } \\
(\mathrm{MPN} / \mathrm{gww})\end{array}$ & $\begin{array}{c}\text { Salmonella } \\
\text { Parasite } \\
\text { eggs }(\mathrm{N} /\end{array}$ \\
$\mathrm{gww})$
\end{tabular}


Table 2 Elemental analysis of samples and approximate chemical formula of raw waste and final composts

\begin{tabular}{lcccccccc}
\hline Sample number & $\mathrm{C} \%$ & $\mathrm{H} \%$ & $\mathrm{~N} \%$ & $\mathrm{~S} \%$ & Ash \% & $\mathrm{O} \%$ & $\mathrm{C} / \mathrm{N}$ ratio & Chemical formula \\
\hline \multicolumn{2}{l}{ Input organic waste } & & & & & & & \\
1 & 37.04 & 4.35 & 1.49 & 0 & 7.75 & 49.37 & 24.86 & $\mathrm{C}_{24.5} \mathrm{H}_{36.8} \mathrm{O}_{28.8} \mathrm{~N}$ \\
2 & 31.42 & 4.13 & 1.89 & 0.04 & 7.74 & 54.78 & 16.62 & \\
3 & 32.50 & 4.37 & 1.49 & 0 & 7.77 & 53.87 & 21.81 & \\
Average & 33.66 & 4.28 & 1.62 & 0.01 & 7.75 & 52.68 & 21.10 & \\
SD & 2.43 & 0.11 & 0.19 & 0.02 & 0.013 & 2.37 & 3.40 & \\
Final vermicompost & & & & & & & \\
1 & 21.67 & 2.80 & 1.72 & 0.47 & 58.74 & 14.60 & 12.60 & $\mathrm{C}_{15.1} \mathrm{H}_{22.4} \mathrm{O}_{7.7} \mathrm{~N}$ \\
2 & 24.24 & 2.98 & 1.82 & 0.40 & 59.10 & 11.46 & 13.32 & \\
3 & 18.90 & 2.30 & 1.43 & 0.40 & 59.34 & 17.63 & 13.22 & \\
Average & 21.60 & 2.69 & 1.66 & 0.42 & 59.06 & 14.57 & 13.05 & \\
SD & 2.18 & 0.29 & 0.17 & 0.03 & 0.25 & 2.52 & 0.32 & \\
Final ASP product & & & & & & & & \\
1 & 20.66 & 2.44 & 1.75 & 0.40 & 46.95 & 27.80 & 11.81 & $\mathrm{C}_{15.2} \mathrm{H}_{21.5} \mathrm{O}_{14.3} \mathrm{~N}$ \\
2 & 22.20 & 2.75 & 1.61 & 0.40 & 46.34 & 26.70 & 13.79 & \\
3 & 21.61 & 2.52 & 1.60 & 0.43 & 47.06 & 26.78 & 13.51 & \\
Average & 21.49 & 2.57 & 1.65 & 0.41 & 46.78 & 27.10 & 13.04 & \\
SD & 0.63 & 0.13 & 0.07 & 0.01 & 0.32 & 0.5 & 0.87 & \\
\hline
\end{tabular}

Table 3 Results of mean values and standard deviations of the measured parameters during the composting process

\begin{tabular}{|c|c|c|c|c|c|c|c|c|c|}
\hline \multirow[t]{2}{*}{ Composting method } & \multirow[t]{2}{*}{ Piles components } & \multicolumn{2}{|c|}{$\mathrm{C} / \mathrm{N}$ ratio } & \multicolumn{2}{|c|}{ Piles temperatures } & \multicolumn{2}{|l|}{$\mathrm{pH}$} & \multicolumn{2}{|c|}{ Moisture (\%) } \\
\hline & & Mean & SD & Mean & SD & Mean & SD & Mean & SD \\
\hline \multirow[t]{3}{*}{ ASP } & $100 \%$ waste & 19.48 & 6.451 & 26.30 & 16.462 & 6.983 & 0.9660 & 54.933 & 9.1656 \\
\hline & $75 \%$ waste & 18.93 & 5.909 & 27.41 & 17.734 & 7.009 & 0.8330 & 54.653 & 8.9238 \\
\hline & Total & 19.20 & 6.167 & 26.85 & 17.062 & 6.996 & 0.8990 & 54.793 & 9.0162 \\
\hline \multirow[t]{3}{*}{ Vermicomposting } & $100 \%$ waste & 18.13 & 6.204 & 22.65 & 12.275 & 7.149 & 0.9888 & 58.773 & 6.4338 \\
\hline & $75 \%$ waste & 17.49 & 6.121 & 23.17 & 12.681 & 7.296 & 0.8922 & 58.867 & 7.3931 \\
\hline & Total & 17.81 & 6.147 & 22.91 & 12.441 & 7.223 & 0.9415 & 58.820 & 6.9069 \\
\hline \multirow[t]{3}{*}{ Total } & $100 \%$ waste & 18.81 & 6.339 & 24.47 & 14.587 & 7.066 & 0.9777 & 56.853 & 8.1235 \\
\hline & $75 \%$ waste & 18.21 & 6.035 & 25.29 & 15.511 & 7.153 & 0.8721 & 56.760 & 8.4358 \\
\hline & Total & 18.51 & 6.184 & 24.88 & 15.036 & 7.109 & 0.9259 & 56.807 & 8.2674 \\
\hline
\end{tabular}

temperature of the even and odd piles in the ASP method was obtained about $4.24{ }^{\circ} \mathrm{C}$ and $3.65^{\circ} \mathrm{C}$, respectively, higher than the similar piles loaded in the vermicomposting method. It is observed that in both methods in the masses included $25 \%$ of cow dung the mean of temperature changes is slightly higher than that of odd-numbered masses.

The average of $\mathrm{pH}$ changes in vermicompost pits is also slightly higher than the aerated static piles. The highest mean of measured $\mathrm{pH}$ is related to the masses containing $25 \%$ of cow dung in the vermicompost method. Due to the activity of earthworms, the average moisture content of vermicompost masses has been measured higher than the ASP masses. The average $\mathrm{C} / \mathrm{N}$ ratio of the ASP masses has been determined more than the average of the $\mathrm{C} / \mathrm{N}$ ratio of vermicompost masses. The highest average of $\mathrm{C} / \mathrm{N}$ ratio was recorded in the masses containing $100 \%$ of household organic wastes in ASP.

The moisture in the process of composting in terms of the comparison between different odd and even piles in both methods is shown in Fig. 2. Static piles' moisture varied from 75 to $80 \%$ at the beginning of the process in accordance with the composition of each pile.

The moisture content of ASP reached about 35-38\% at the end of the process. In case of vermicomposting masses, the moisture begins within the range of $77-79 \%$ (pits loading) and then decreases to about $50 \%$ at the end of the process. In aerated static piles, while maintaining humidity 

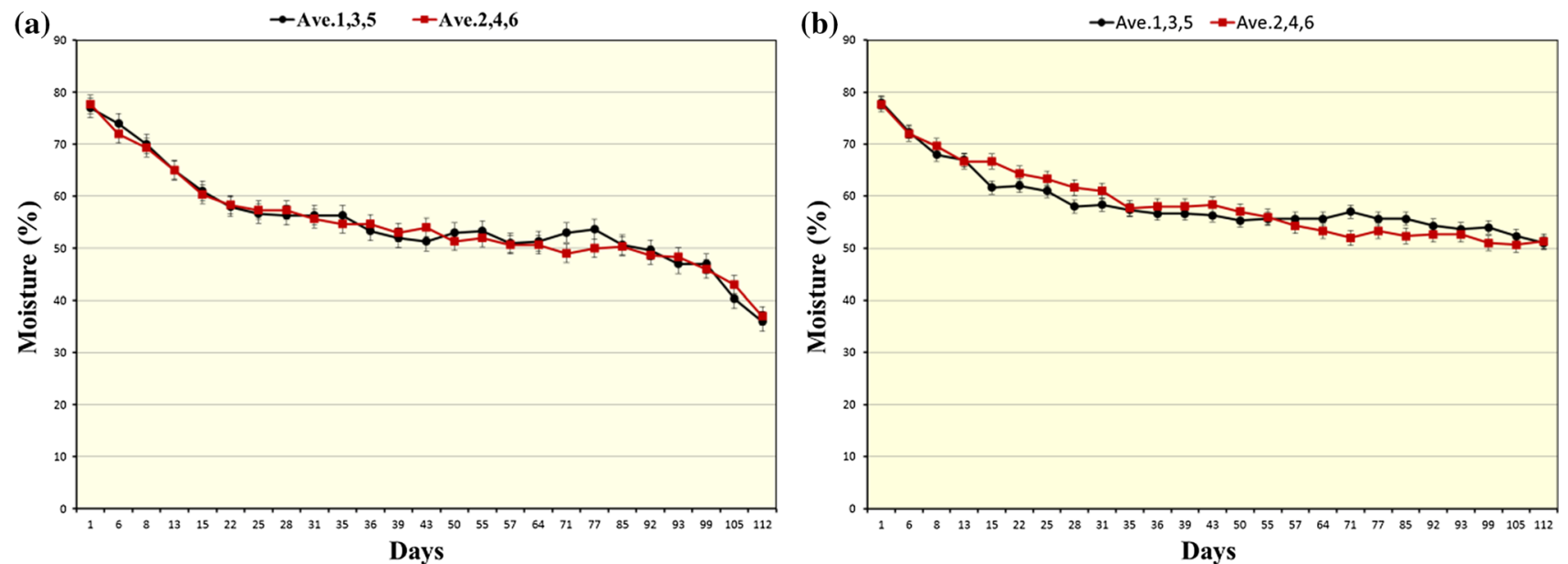

Fig. 2 Changes in moisture contents between different piles, a $\mathrm{ASP}\left(\mathrm{SD}_{1,3,5}=9.16 / \mathrm{SD}_{2,4,6}=8.92\right)$ and $\mathbf{b}$ vermicomposting $\left(\mathrm{SD}_{1,3,5}=6.43 /\right.$ $\left.\mathrm{SD}_{2,4,6}=7.39\right)$

within a reasonable range, it was observed thermophilic phase conditions prevailed during the days 8-24 and that the piles had the optimum temperature for thermophilic bacteria activity. In the vermicompost process, thermophilic phase moves with a lower slope than the static method and has been at the minimum operating temperature range $\left(25-45^{\circ} \mathrm{C}\right)$ for thermophilic bacteria activity. Conditions for piles containing $25 \%$ cow dung are slightly better than piles containing $100 \%$ organic wastes. Compost moisture content had an influence on the temperature during the composting process, especially during the later stages of monitoring when the external temperature was higher (Storino et al. 2016).

The $\mathrm{pH}$ increased in all samples during the composting period. Earthworms and micro-organisms are able to change the soil pH (Suthar et al. 2015). Intense microbial activity and decomposition of organic matter resulted in the formation of ammonium and increased $\mathrm{pH}$ of the compost. In the final stages, the activity of micro-organisms affecting the decomposition increased during the process of aerobic metabolism and in the presence of sufficient moisture which results in the production of alkaline products. At this stage, $\mathrm{pH}$ has been fixed and in some piles a little decreased which could be attributed to the production of $\mathrm{CO}_{2}$ due to the metabolic activities of earthworms and micro-organisms in vermicomposting pits and ASP (Amouei et al. 2017). The results of temperatures and the $\mathrm{C} / \mathrm{N}$ ratio during the composting process as the comparison between different compositions (odd and even piles) in both ASP and vermicomposting are provided in Figs. 3 and 4. By the analysis of variance and using the software SPSS, the combined effects of factors on each variable was examined. By studying the significance level of the Fisher test, it was observed the individual effect of aeration (Sig. $=0.000$ and $F=18.730$ ) on the dependent variable moisture was significant. It means that statistically the average of moisture content between different levels of aeration was not similar and invariant. The individual effect of waste percentage (Sig. $=0.920$ and $F=0.010$ ) was not significant on the dependent variable moisture. It means that the moisture average was statistically invariant and uniform between different levels of the waste percentage.

As can be seen in both compost production methods (Fig. 4), the $\mathrm{C} / \mathrm{N}$ ratio has decreased mainly due to the conversion of organic carbon into carbon dioxide. According to the results of the measured parameters, it has been cleared that the average of the $\mathrm{C} / \mathrm{N}$ ratio of the piles in the static method is more than that of vermicompost. The main reason for this can be related to more use of cow dung (which has less $\mathrm{C} / \mathrm{N}$ ratio) in the vermicomposting piles. In addition, the average $\mathrm{C} / \mathrm{N}$ ratio in odd piles $(100 \%$ of organic wastes) is more than of the even piles $(75 \%$ organic wastes and $25 \%$ of cow dung) in each of the two methods. The average $\mathrm{C} / \mathrm{N}$ ratio in odd piles in the ASP method is more than that of the same piles in the vermicompost piles. This is true for even piles as well.

The combined effect of aeration and waste percentage is not significant on the dependent variable moisture content. Therefore, statistically speaking, the moisture average in different levels and the combined effect of aeration and waste percentage was not different because the Sig. value is more than 0.05 and is equal to 0.841 . In addition, the coefficient ' $R$ Squared', whose adjusted value is equal to 0.05 , indicates that these two factors could explain that about $5 \%$ of the variance in moisture was variable.

The individual effect of aeration (Sig. $=0.034$ and $F=4.532$ ) on the dependent variable $\mathrm{pH}$ was significant. It means that the average of $\mathrm{pH}$ between different levels of aeration was not similar and invariant. In other words, with a confidence of $95 \%$, the $\mathrm{pH}$ value is different at different 

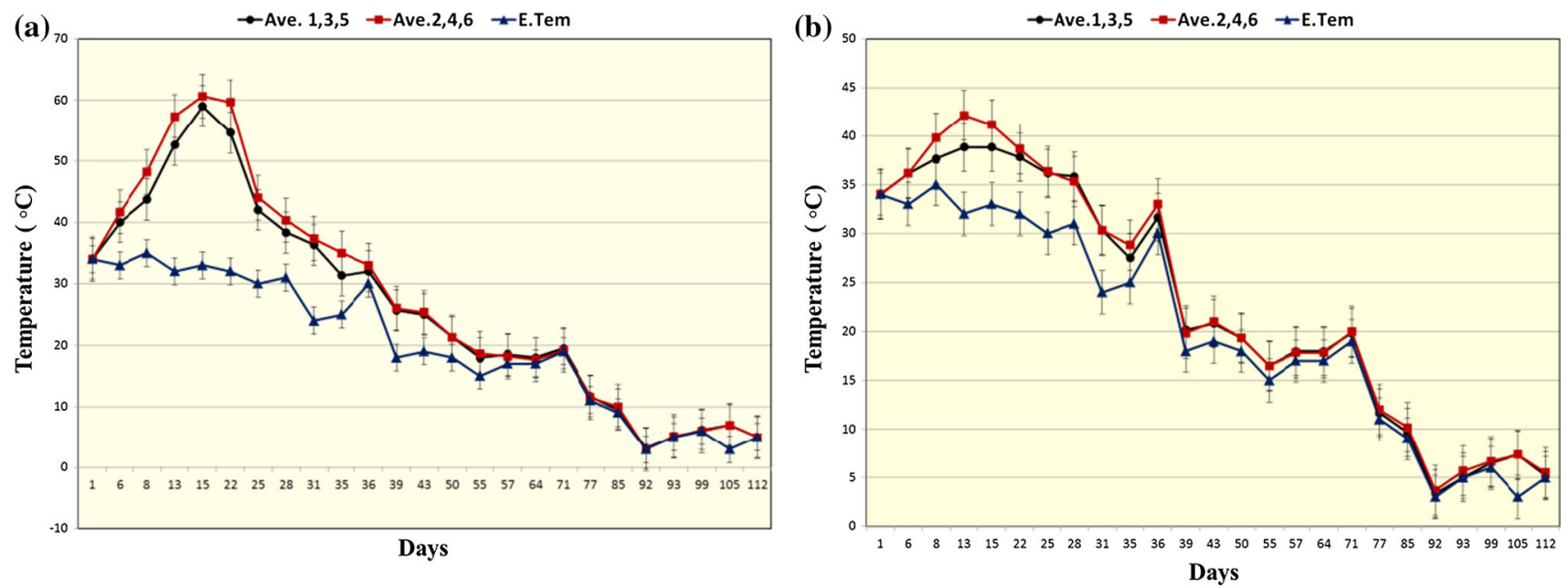

Fig. 3 Changes in temperature (piles and environment), a $\operatorname{ASP}\left(\mathrm{SD}_{1,3,5}=16.4 / \mathrm{SD}_{2,4,6}=17.7\right)$ and b vermicomposting $\left(\mathrm{SD}_{1,3,5}=12.2 /\right.$ $\left.\mathrm{SD}_{2,4,6}=12.6\right)$
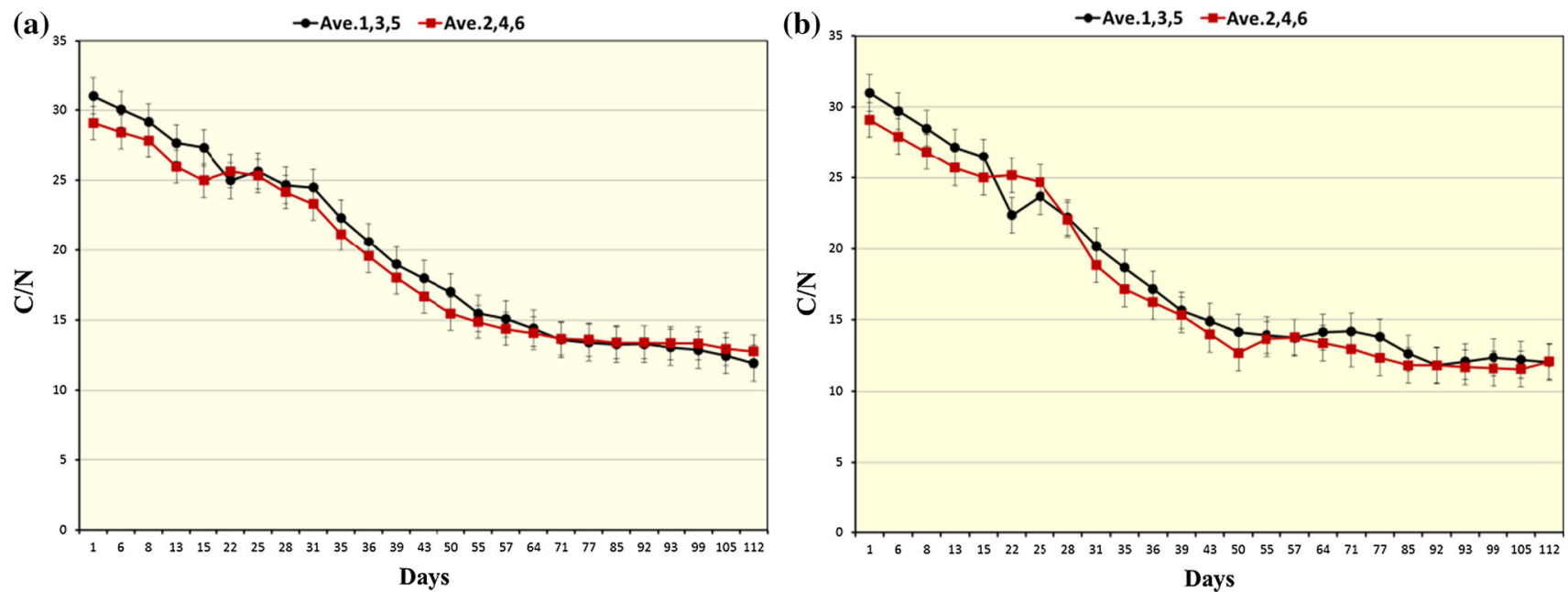

Fig. 4 Changes in the $\mathrm{C} / \mathrm{N}$ ratio between different piles, a $\mathrm{ASP}\left(\mathrm{SD}_{1,3,5}=6.45 / \mathrm{SD}_{2,4,6}=5.91\right)$ and $\mathbf{b}$ vermicomposting $\left(\mathrm{SD}_{1,3,5}=6.20 /\right.$ $\left.\mathrm{SD}_{2,4,6}=6.12\right)$

levels of aeration. The individual effect of waste percentage (Sig. $=0.416$ and $F=0.663$ ) was not significant on the dependent variable $\mathrm{pH}$. So, the average of $\mathrm{pH}$ between different levels of waste percentage was invariant. Combined effect of aeration and waste percentage is not significant on the dependent variable $\mathrm{pH}$. As a result, the $\mathrm{pH}$ average in different levels and the combined effect of aeration and waste percentage was not different because the Sig. value was more than 0.05 and was equal to 0.573 . The adjusted value of the coefficient ' $R$ Squared' in this study was 0.008 . Higher $\mathrm{pH}$ levels in the vermicompost system compared to static piles are directly related to worm castings. Excretion of calcium from calcium glands into the food and soil and passing through the worms' intestine and digestive system causes an increase in $\mathrm{pH}$. In addition to intestinal secretions, production and secretion of ammonia by the action of worms is also effective. Increasing the $\mathrm{pH}$ level in vermicomposting piles may indicate the reduction in oxygen level in contrast to the ASP.

The individual effect of aeration on the dependent variable piles' temperature was significant. But the individual effect of waste percentage and the combined effect of these two factors on the dependent variable piles' temperature were not significant. So, the piles' temperature average at different levels and the combined effect of aeration and waste percentage were not different because the Sig. value was more than 0.05 and equal to 0.865 . The adjusted value of the coefficient ' $R$ Squared' was found to be 0.008 . The domain of temperature changes in ASP is greater than the temperature changes in vermicomposting.

The above figures show that in the thermophilic phase of the static method, piles' temperature reached to the border of $60{ }^{\circ} \mathrm{C}$, while the maximum temperature recorded in the vermicompost pits is related to pile Number 6 and is about 
$43{ }^{\circ} \mathrm{C}$. The maximum temperature related to the thermophilic phase in two methods differs by about $20^{\circ} \mathrm{C}$. This is very important in eliminating pathogens and harmful micro-organisms, causing intuitive differences in the two methods. It is noteworthy that in both methods, even piles (containing 25\% of cow manure) in terms of the average temperature are slightly more than of odd piles (including only organic waste).

By measuring the temperatures at various depths and areas of piles, it was observed that areas with higher temperature were closer to the outer surface in case of vermicomposting masses. This is owing to the higher humidity of vermicompost in comparison with ASP. Because of the high moisture at the centre of vermicompost piles, the development of anaerobic conditions may happen.

The individual effect of aeration (Sig. $=0.075$ and $F=3.199$ ), individual effect of waste percentage (Sig. $=0.445$ and $F=0.584$ ) and the combined effect of these two factors on the dependent variable of the $\mathrm{C} / \mathrm{N}$ ratio $($ Sig. $=0.952)$ were not significant. The adjusted value of the coefficient ' $R$ Squared' was found to be 0.003 .

By using the Kolmogorov-Smirnov test, it is evident that the data were not normal. Therefore, in order to study the correlation between measured variables (moisture, $\mathrm{pH}$ and mean of piles' temperature) with carbon-to-nitrogen ratio and also to show the relationship between the mentioned variables and the dependent variable ( $\mathrm{C} / \mathrm{N}$ ratio), the dispersal graph was drawn. Finally, for determining significant relationship between variables, parametric Pearson and nonparametric Spearman tests were used. The results of this analysis are presented in Table 4. This table shows that in both ASP and vermicompost, there is a direct relationship between the $\mathrm{C} / \mathrm{N}$ ratio and the masses' moisture and also between the $\mathrm{C} / \mathrm{N}$ ratio and the mean of piles' temperature. In contrast, between the $\mathrm{C} / \mathrm{N}$ ratio and $\mathrm{pH}$, inverse relationship is clear. Using one-way ANOVA resulted in the fact that the $\mathrm{C} / \mathrm{N}$ ratio at different levels of composting process period with a confidence level of $95 \%$ was different for both methods used in this study. During the composting process, eight samples were taken by the ammonia gas detector tube and the amount of $\mathrm{NH}_{3}$ emissions was read. Ammonia gas emissions increasing along with the rising temperature of the piles in the thermophilic phase in both ASP and vermicomposting could be related to deactivation and activity reduction in Nitrosomonas bacteria at temperatures higher than $40{ }^{\circ} \mathrm{C}$. During the composting process (mesophilic phase) in both methods, based on the recorded levels, the release of ammonia gas is declining. This is because during the process, ammonia nitrogen decreases and the amount of nitrate nitrogen increase due to Nitrobacter activities (Haug 1996).

Field measurements show that the output of ammonia concentration during the vermicomposting process is more than the ASP. This can be due to more cow dung (as bedding for the worms has been placed in all vermicomposting masses) compared to the static method and because of the worms' activity in the vermicompost piles and also worms' intestinal ammonia excretion (Abdoli and Roshani 2007; Munroe 2004). The maximum concentration of ammonium and $\mathrm{NH}_{3}$ production in the piles is in the early weeks when the percentage of organic matter in the masses is in the maximum levels. The maximum emission of ammonia gas in vermicompost piles was measured as $37 \mathrm{ppm}$ and was $32 \mathrm{ppm}$ in ASP. At the end of the process, the amount of ammonia in the piles was in its minimum levels so that it was nearly zero in the static method and reached to the border $2 \mathrm{ppm}$ in vermicomposting.

\section{Comparison of microbial characteristics of finished compost in two methods}

In order to compare the microbial quality of matured compost, four samples, including two samples of piles (5 and 6 of ASP) and two samples (pits 5 and 6), of the

Table 4 Pearson parametric and nonparametric Spearman test results for studying the relationship between the dependent variable $\mathrm{C} / \mathrm{N}$ ratio and other variables

\begin{tabular}{|c|c|c|c|c|c|c|c|c|}
\hline \multirow[t]{2}{*}{$\begin{array}{l}\text { Dependent } \\
\text { variable }\end{array}$} & \multirow[t]{2}{*}{ Test } & & \multicolumn{2}{|l|}{$\begin{array}{l}\text { Mean of piles' } \\
\text { temperature }\end{array}$} & \multicolumn{2}{|l|}{$\mathrm{pH}$} & \multicolumn{2}{|l|}{ Moisture } \\
\hline & & & vermicompost & ASP & vermicompost & ASP & vermicompost & ASP \\
\hline \multirow[t]{6}{*}{$\mathrm{C} / \mathrm{N}$ ratio } & \multirow{3}{*}{ Pearson (parametric) } & Pearson correlation & 0.878 & 0.886 & -0.943 & -0.933 & 0.887 & 0.854 \\
\hline & & Sig. (two-tailed) & 0.000 & 0.000 & 0.000 & 0.000 & 0.000 & 0.000 \\
\hline & & $\mathrm{N}$ & 126 & 126 & 126 & 126 & 126 & 126 \\
\hline & \multirow[t]{3}{*}{ Spearman (nonparametric) } & Spearman's rho & 0.890 & 0.878 & -0.885 & -0.912 & 0.857 & 0.909 \\
\hline & & Sig. (two-tailed) & 0.000 & 0.000 & 0.000 & 0.000 & 0.000 & 0.000 \\
\hline & & $\mathrm{N}$ & 126 & 126 & 126 & 126 & 126 & 126 \\
\hline
\end{tabular}


vermicomposting system have been taken. A comparison of the two methods showed that the reduction in the amount of total coliforms and faecal coliforms in both systems has occurred, and this reduction in the static method is more than vermicompost. The amount of faecal coliforms in input wastes was significantly higher than $1000 \mathrm{MPN} / \mathrm{g}$. (In samples containing $100 \%$ organic waste, it was counted $2 \times 10^{4} \mathrm{MPN} / \mathrm{gdw}$, while in the mixed samples of organic waste and cow dung was measured around $1.1 \times 10^{6} \mathrm{MPN} / \mathrm{gdw}$.) This amount in the final compost greatly reduced and reached $28 \mathrm{MPN} / \mathrm{g}$ in sample 'ASP 6' and less than $3 \mathrm{MPN} / \mathrm{g}$ in the other three samples. In case of Salmonella, it was not detected in the final product in both methods. Total coliforms in the final product of vermicompost is 16 times of the product obtained in ASP for $100 \%$ organic waste composition and nearly 180 times of ASP-finished compost for $75 \%$ organic waste composition. The total coliform reduction in ASP piles containing $100 \%$ organic wastes was observed about $3 \log$, and for vermicomposting piles, this reduction was about $2 \log$. This reduction in piles containing $75 \%$ organic wastes was considered about $4 \log$ for ASP and about $2 \log$ for vermicomposting.

The reduction in parasite eggs in piles containing $100 \%$ organic wastes for ASP was about $75.8 \%$ and was considered as about $24.2 \%$ for vermicomposting piles, and for mixture of organic waste and cow dung $(75 \%$ organic wastes and $25 \%$ cow dung), about $95 \%$ was observed for ASP and $90 \%$ for vermicomposting piles. Microbial characteristics of final products obtained from two methods were in the range of Iran standard No. 13321-1 (it is classified in Category ' $A$ ' and could be used in agricultural lands without restriction), US standard (USEPA 40CFR, part 503) and Canadian standard (CCME 2005).

Temperature changes measured for aerated static piles are in the ranges mentioned in both US and Canadian standards (operating conditions of $55^{\circ} \mathrm{C}$ or greater for at least 3 days). For vermicomposting piles in this study, because the masses' temperature didn't reach over $55^{\circ} \mathrm{C}$, they are not in the range of the above standards.

\section{Comparison of chemical characteristics of finished compost in two methods}

In both composting and vermicomposting processes, the presence of heavy metals and different toxics substances limits its land use without processing. The production and application of compost potentially contaminate the environment with heavy metals (Mohee and Soobhany 2014). Comparison of the chemical quality of the finished products in both the studied methods showed that the organic matter in matured vermicompost and ASP final compost was 34.38 and $38.16 \%$, respectively. The $\mathrm{NH}_{4}-\mathrm{N} / \mathrm{NO}_{3}-\mathrm{N}$ ratio was measured about 1.8 for vermicompost final product and 1.95 for matured compost produced in ASP method. The concentration of $\mathrm{Cu}$ in finished vermicompost is nearly twice the static product (41.13 vs. $21.2 \mathrm{ppm}$ ), but it is still within the allowable range of national and international standards. Other heavy metals (lead, cadmium and nickel) in the final products were not recognizable due to the lack of concentration. An important reason for the low concentration of heavy metals is lack of industrial waste entering the waste stream as well as organic waste separation from other waste components of the village. $\mathrm{K}_{2} \mathrm{O}$, $\mathrm{P}_{2} \mathrm{O}_{5}$ and $\mathrm{EC}$ in final product of vermicompost were measured about $1.32,1.22 \%$ and $4.87 \mathrm{Ds} / \mathrm{m}$, and those of ASP final product were $1.75,1.84 \%$ and $8.13 \mathrm{Ds} / \mathrm{m}$, respectively.

In ASP, the $\mathrm{C} / \mathrm{N}$ ratio changes from 10.2 to 14.6 for the final product with an average of 12.35 . In return, the $\mathrm{C} / \mathrm{N}$ ratio for finished vermicompost changes from 10.3 to approximately 13.8 with a total average of 12.05 . The summary of $\mathrm{C} / \mathrm{N}$ and $\mathrm{pH}$ value determination is provided in Table 5. These amounts of $\mathrm{C} / \mathrm{N}$ ratio for the final products are within the range of 10-15, which is ideal for final stabilized composts (Kadir et al. 2016). The amount of organic matter, $\mathrm{C} / \mathrm{N}$ ratio, $\mathrm{pH}$, moisture content and heavy metal limits of final products in both methods (ASP and vermicomposting) are in the ranges expressed in the US standard. The organic matter content and cation exchange capacity of final vermicompost were high, indicating that it was rich in nutrients and therefore suitable as organic amendment. These results are in agreement with the results of a research conducted by Alvarez-Bernal et al. (2016). CEC was measured about 100 and $96 \mathrm{meq} / 100 \mathrm{~g}$ for vermicompost and ASP-finished product, respectively.

In terms of electrical conductivity, the final product of vermicompost is placed in an allowable range of the US standard and is within the medium range (between 2 and $5 \mathrm{mmhos} / \mathrm{cm}$ ), while the product obtained from the ASP method is located in the lower-tier application: M-High. This means that vermicompost compared to static final compost requires less dilution for agricultural use in different applications. Higher values in ASP indicate a larger amount of soluble minerals that may inhibit biological activity or cause problems with land applications (if large quantities of the compost are used). The $\mathrm{NH}_{4}-\mathrm{N}-$ to- $\mathrm{NO}_{3}-\mathrm{N}$ ratio for ASP and vermicomposting the final product was measured around 1.95 and 1.8, respectively, which are placed within the range of USEPA limits for matured compost.

Comparing with Canadian standards, the finished compost was produced in both methods and is within the allowable range of these standards in terms of organic matters such as the $\mathrm{C} / \mathrm{N}$ ratio, $\mathrm{pH}$, moisture and heavy 
Table 5 Comparison the average and standard deviation of organic carbon, Kjeldahl nitrogen, $\mathrm{C} / \mathrm{N}$ and $\mathrm{pH}$ values in the matured compost

\begin{tabular}{lllll}
\hline Composting method & OC $\%$ & Kjeldahl nitrogen $\%$ & C/N & $\mathrm{pH}$ \\
\hline ASP odd piles & $23.41(2.27)^{\mathrm{a}}$ & $1.97(0.12)$ & $11.94(1.29)$ & $8.03(0.05)$ \\
ASP even piles & $26.29(1.16)$ & $2.17(0.16)$ & $12.80(1.37)$ & $8.07(0.12)$ \\
Average (ASP) & $24.85(1.44)$ & $2.02(0.11)$ & $12.35(0.43)$ & $8.05(0.02)$ \\
Vermicomposting odd piles & $24.32(1.11)$ & $2.13(0.4)$ & $11.7(1.7)$ & $8.23(0.09)$ \\
Vermicomposting even piles & $25.11(0.96)$ & $2.10(0.16)$ & $12.06(1.4)$ & $8.13(0.12)$ \\
Average (vermicomposting pits) & $24.72(0.40)$ & $2.12(0.02)$ & $12.05(0.25)$ & $8.18(0.05)$ \\
\hline
\end{tabular}

${ }^{a}$ The values in parentheses indicate the standard deviation of the data
Fig. 5 Comparison of changes in the net present value for both static and vermicomposting methods

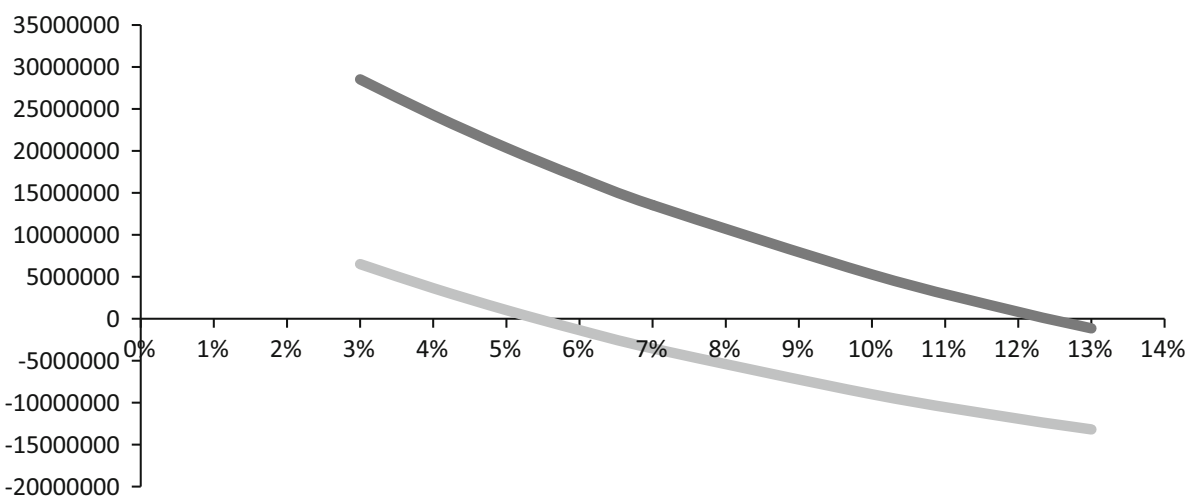

metal limitation. It should be considered that both final products are classified in Group B of the Canadian BNQ Standard in terms of total organic matters, but both pass the minimum amount of total organic matters in the compost quality standard of Ontario (2012). In terms of electrical conductivity, the finished vermicompost is almost within the range of the compost quality standard of Ontario (Canada), and the compost obtained from static piles is not within the allowable range of this standard (Interim Guidelines for the Production and Use of Aerobic Compost in Ontario 2004).

Comparing the final product in the static method with the Iranian national standard 10716 and the final product in the vermicomposting method with the Iranian national standard 13724 implies that the end product in both composting methods is classified in Category A of the standards.

\section{Economic assessment of ASP and vermicomposting}

High-quality compost should be produced to overcome the cost of composting. The cost of composting of animal manures can be considerably higher than the direct utilization of raw manures (Bernal et al. 2009). After determining start-up (initial investment) and operational costs for both methods, the net present value (NPV) and internal rate of return (IRR) for the discount rate of $6 \%$, tax rate of
$7 \%$ and lifetime of 10 years were calculated using the software COMFAR III.

The important assumptions used in the economic assessment were: (1) the government does not allocate any loan, (2) initial investment and construction materials' costs and also the equipment used (blower, aeration pipes, etc.) were determined in accordance with the pilot conditions, (3) physicochemical and microbial experiments in order to determine the specifications of input wastes and monitoring of compost process were performed according to the hypotheses and objectives stated in the study. The costs of these tests were also considered in the economic assessment, (4) current expenses (water, electricity and labour costs) were considered in this assessment too, (5) annual depreciation expenses for two methods of composting were calculated based on initial set-up and operating costs and NPV was determined for both methods separately.

Owing to the negative NPV value for the vermicomposting method and positive NPV for the static method, in this discount rate, it can be stated that ASP will be more attractive for private sector investor. The internal rate of return in the vermicomposting method is equivalent to $5.4 \%$. In other words, if an investor's expected return from the investment amount is about $5.4 \%$ or less (i.e. at rates the NPV to be positive), the investor is much more willing to invest in producing compost using the vermicomposting method. 
The internal rate of return in the static method is equivalent to $12.4 \%$, which represents that if the investors expect output more than $12.4 \%$ of their investment funds, the project will not be economically feasible for them. As a result, the net present value at all discount rates for the static method is more of the vermicomposting system. This is also well confirmed in Fig. 5. In this figure, the black curve (upper line) represents NPV in ASP, and the grey curve (bottom line) represents NPV in vermicomposting pits.

\section{Conclusion}

In total, the final compost produced in both methods which was carried out from September 2015 to January 2016 had dark brown-black colour and no unpleasant smell. From the standpoint of the emotional indicators, it can be stated that the static method product compared with vermicomposting final product had slightly more pleasant smell. Both products had good quality and were satisfying. The static final product in terms of attracting insects was better than the final product of vermicompost. Comparing final products with Iranian standards, USEPA and CCME show that both methods have stabilized input wastes (both input materials containing 100 and $75 \%$ organic wastes) and eventually led to produce good compost. The results indicate that the processing time in ASP is about 15-20 days shorter than of the processing and maturation time of compost in the vermicomposting method. A stable and mature vermicompost was obtained after 110 days which is in agreement with the results of a similar research conducted by Alvarez-Bernal et al. (2016). Gupta et al. (2007) reported 147 days to obtain stable and mature vermicompost.

Odours emitted from the composting piles along with $\mathrm{NH}_{4}-\mathrm{N}: \mathrm{NO}_{3}-\mathrm{N}$ determination, temperature and moisture measurement as well as ammonia gas emissions measured in two methods clearly show this matter. Owing to the relatively high levels of total coliforms remaining in the final product of vermicomposting pits, enough time between the use of compost and harvesting be considered for crops that are in contact with the ground. In terms of CEC, the final product in the vermicomposting method had better quality compared to the standards.

Finally, in terms of the economic assessment of the two composting methods, it was observed that the ASP method in long term (lifetime 10 years) has greater NPV compared to vermicomposting, which will be more suitable for the investor. The internal rate of return for ASP is $12.4 \%$, and it is $5.4 \%$ for the vermicomposting method. According to the results, it can be concluded that the use of vermicomposting in order to convert household putrescible wastes into compost and ASP for centralized management of organic waste by rural municipalities could be more suitable, and adding $25 \%$ of cow manure to input materials improves the quality of the final product.

Acknowledgements The authors would like to thank the rural municipality of Sooleghan village, Tehran, Iran, for providing in field labours and facilities.

Open Access This article is distributed under the terms of the Creative Commons Attribution 4.0 International License (http:// creativecommons.org/licenses/by/4.0/), which permits unrestricted use, distribution, and reproduction in any medium, provided you give appropriate credit to the original author(s) and the source, provide a link to the Creative Commons license, and indicate if changes were made.

\section{References}

Abdoli MA, Roshani MR (2007) Vermicompost: design, build and implementation. Tehran University Press, Tehran

Alberta Environment \& Olds College (1999) Midscale composting manual. Alberta \& Olds College, Alberta

Alvarez-Bernal D, Lastiri Hernández MA, Buelna Osben HR, Contreras Ramos SM, Mora M (2016) Vermicompost as an alternative of management for water hyacinth. Rev Int Contam Ambie 32(4):425-433. doi:10.20937/RICA.2016.32.04.06

Amouei AI, Yousefi Z, Khosravi T (2017) Comparison of vermicompost characteristics produced from sewage sludge of wood and paper industry and household solid wastes. J Environ Health Sci Eng. doi:10.1186/s40201-017-0269-Z

Anwar Z, Irshad M, Fareed I, Saleem A (2015) Characterization and recycling of organic waste after Co-composting-a review. J Agric Sci. doi:10.5539/jas.v7n4p68

Barrena R, Font X, Gabarrell X, Sánchez A (2014) Home composting versus industrial composting: influence of composting system on compost quality with focus on compost stability. Waste Manag 34:1109-1116. doi:10.1016/j.wasman.2014.02.008

Bernal MP, Alburquerque JA, Moral R (2009) Composting of animal manures and chemical criteria for compost maturity assessment. A review. Bioresour Technol 100(22):5444-5453. doi:10.1016/j. biortech.2008.11.027

Bertoldi M, Sequi P, Lemmes B, Papi T (1996) The science of composting. Blackie Academic \& Professional, an imprint of Chapman \& Hall, London

Brinton WF, Bonhotal J, Fiesinger T (2012) Compost sampling for nutrient and quality parameters: variability of sampler, timing and pile depth. Taylor Francis Group Compost Sci Util 20(3):141-149

Brito LM, Mourão I, Coutinho J, Smith SR (2012) Simple technologies for on-farm composting of cattle slurry solid fraction. Waste Manag 32(7):1332-1340. doi:10.1016/j.wasman.2012.03.013

Brown MB, Gage J (2015) Lessons Learned in aerated static pile (ASP) composting. Compost Des Serv, Olympia

CCME: Canadian Council of Ministers of the Environment (2005) Guidelines for Compost Quality. PN 1340, Canada

Gupta R, Mutiyar PK, Rawat NK, Saini MS, Garg VK (2007) Development of a water hyacinth based vermireactor using an epigeic earthworm Eisenia foetida. Bioresour Technol 98(13):2605-2610. doi:10.1016/j.biortech.2006.09.007

Haug RT (1996) Composting plant design and process management. Chapman \& Hall, USA 
Huang J, Yu Z, Gao H, Yan X, Chang J, Wang C, Hu J, Zhang L (2017) Chemical structures and characteristics of animal manures and composts during composting and assessment of maturity indices. PLoS ONE. doi:10.1371/journal.pone.0178110

Iranian Municipalities and Rural Municipalities Organization (2010) Comprehensive studies of rural wastes. Motahari, Qom

Kadir AA, Jamaludin SN, Azhari NW (2016) An overview of composting based on variable feedstock material. MATEC Web Conf 47:05016. doi:10.1051/matecconf/20164705016

Komilis D, Evangelou A, Giannakis G, Lymperis C (2012) Revisiting the elemental composition and the calorific value of the organic fraction of municipal solid wastes. Waste Manag 32(3):372-381. doi:10.1016/j.wasman.2011.10.034

Liwarska-Bizukojc E, Ledakowicz S (2003) Stoichiometry of the aerobic biodegradation of the organic fraction of municipal solid waste (MSW). Biodegradation 14(1):51-56. doi:10.1023/A: 1023538123655

Ministry of the Environment- Ontario Interim (2004) Guidelines for the production and use of aerobic compost in Ontario, Ontario, Canada

Mohee R, Soobhany N (2014) Comparison of heavy metals content in compost against vermicompost of organic solid waste: past and present. Resour Conserv Recycl 92:206-213. doi:10.1016/j. resconrec.2014.07.004

Munroe G (2004) Manual of on-farm vermicomposting and vermiculture. Organic Agriculture Centre of Canada (OACC), Canada

Mupondi LT, Mnkeni PN, Muchaonyerwa P (2011) Effects of a precomposting step on the vermicomposting of dairy manure- waste paper mixtures. Waste Manag 29:219-228. doi:10.1177/ $0734242 X 10363142$

Ontario Ministry of the Environment, Waste Management Policy Branch (2012) Ontario Compost Quality Standards, Ontario

Qian X, Shen G, Wang Z, Guo C, Liu Y, Lei Z, Zhang Z (2014) Cocomposting of livestock manure with rice straw: characterization and establishment of maturity evaluation system. Waste Manag 34(2):530-535. doi:10.1016/j.wasman.2013.10.007

Razmjoo P, Pourzamani H, Teiri H, Hajizadeh Y (2015) Determination of an empirical formula for organic composition of mature compost produced in Isfahan-Iran composting plant in 2013. Int J Environ Health Eng. doi:10.4103/2277-9183.153988

Storino F, Menéndez S, Muro J, Aparicio-Tejo PM, Irigoyen I (2016) Effect of feeding regime on composting in bins. Taylor Francis Group Compost Sci Util 25(2):71-81. doi:10.1080/1065657X. 2016.1202794

Suthar S, Kumar K, Mutiyar PK (2015) Nutrient recovery from compostable fractions of municipal solid wastes using vermitechnology. J Mater Cycles Waste Manag 17:174-184. doi:10. 1007/s10163-014-0238-x

Tchobanoglous G, Kreith F (2002) Handbook of solid waste management. McGraw-Hill, New York

Test Methods for the Examination of Composting and Compost (TMECC) (2002) Field sampling of compost materials, method 02.01-A, compost sampling principles. U.S. Composting Council. http://compostingcouncil.org/ TMECC (verified Oct 25 2011)

Woods End Laboratories (2016) Principals and practice: compost sampling for lab analysis. Woods End Laboratories Inc, USA 